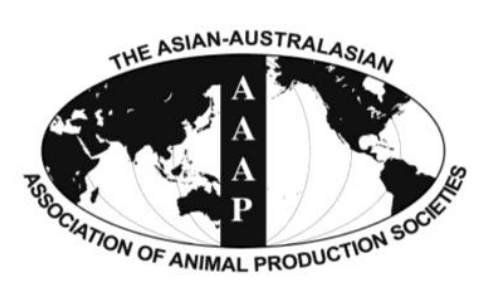

Open Access

Asian Australas. J. Anim. Sci. Vol. 27, No. 10 : 1426-1435 October 2014 http://dx.doi.org/10.5713/ajas.2014.14086

\title{
Meta-analysis on Methane Mitigating Properties of Saponin-rich Sources in the Rumen: Influence of Addition Levels and Plant Sources
}

\author{
Anuraga Jayanegara ${ }^{1 * *}$, Elizabeth Wina $^{2}$, and Junichi Takahashi ${ }^{1,3}$ \\ ${ }^{1}$ Department of Animal Nutrition and Feed Technology, Faculty of Animal Science, \\ Bogor Agricultural University, Bogor 16680, Indonesia
}

\begin{abstract}
Saponins have been considered as promising natural substances for mitigating methane emissions from ruminants. However, studies reported that addition of saponin-rich sources often arrived at contrasting results, i.e. either it decreased methane or it did not. The aim of the present study was to assess ruminal methane emissions through a meta-analytical approach of integrating related studies from published papers which described various levels of different saponin-rich sources being added to ruminant feed. A database was constructed from published literature reporting the addition of saponin-rich sources at various levels and then monitoring ruminal methane emissions in vitro. Accordingly, levels of saponin-rich source additions as well as different saponin sources were specified in the database. Apart from methane, other related rumen fermentation parameters were also included in the database, i.e. organic matter digestibility, gas production, $\mathrm{pH}$, ammonia concentration, short-chain fatty acid profiles and protozoal count. A total of 23 studies comprised of 89 data points met the inclusion criteria. The data obtained were subsequently subjected to a statistical meta-analysis based on mixed model methodology. Accordingly, different studies were treated as random effects whereas levels of saponin-rich source additions or different saponin sources were considered as fixed effects. Model statistics used were p-value and root mean square error. Results showed that an addition of increasing levels of a saponin-rich source decreased methane emission per unit of substrate incubated as well as per unit of total gas produced $(\mathrm{p}<0.05)$. There was a decrease in acetate proportion (linear pattern; $p<0.001)$ and an increase in propionate proportion (linear pattern; $\mathrm{p}<0.001$ ) with increasing levels of saponin. Log protozoal count decreased $(\mathrm{p}<0.05)$ at higher saponin levels. Comparing between different saponin-rich sources, all saponin sources, i.e. quillaja, tea and yucca saponins produced less methane per unit of total gas than that of control $(\mathrm{p}<0.05)$. Although numerically the order of effectiveness of saponin-rich sources in mitigating methane was yucca>tea>quillaja, statistically they did not differ each other. It can be concluded that methane mitigating properties of saponins in the rumen are level- and source-dependent. (Key Words: Saponin, Methane, Rumen, Emission, Fermentation)
\end{abstract}

\section{INTRODUCTION}

The problem of global warming due to accumulation of various green-house gases (GHG) such as carbon dioxide $\left(\mathrm{CO}_{2}\right)$, methane $\left(\mathrm{CH}_{4}\right)$ and nitrous oxide $\left(\mathrm{N}_{2} \mathrm{O}\right)$ has received serious attention during the past decades. Livestock, especially ruminants, are considered as considerable

\footnotetext{
* Corresponding Author: Anuraga Jayanegara. Tel: +62-251-862 6213, Fax: +62-251-8626213, E-mail: anu_jayanegara@yahoo.com ${ }^{2}$ Indonesian Research Institute for Animal Production, Bogor 16002, Indonesia.

${ }^{3}$ School of Animal Science, Obihiro University of Agriculture and Veterinary Medicine, Obihiro, Hokkaido 080-8555, Japan. Submitted Feb. 6, 2014; Revised Mar. 30, 2014; Accepted May 6, 2014
}

contributors to the increase in the atmospheric $\mathrm{CH}_{4}$ level, either from enteric fermentation or from manure (Lassey, 2008). A review conducted by Thorpe (2009) showed that annually ruminants produce 80 to $115 \mathrm{Tg} \mathrm{CH}_{4}$. Apart from its contribution to global warming, $\mathrm{CH}_{4}$ emissions from livestock also represents a loss of energy from the animals (Monteny et al., 2006). The amount of energy loss as $\mathrm{CH}_{4}$ within ruminant animals may account for $6 \%$ to $10 \%$ of gross energy intake, or $8 \%$ to $14 \%$ of digestible energy intake (Cottle et al., 2011). Such energy loss actually could potentially be conserved, at least partially, for a more useful purpose like production or reproduction. Therefore, effective $\mathrm{CH}_{4}$ mitigation measurements would benefit not only the environment but also the productivity of animals. 
An approach to mitigate enteric $\mathrm{CH}_{4}$ emission is through nutritional manipulation. Accordingly, various nutritional attempts have been made to mitigate the respective GHG emission, and those could be clustered into ration manipulations, use of additives or biotechnological approaches (Van Nevel and Demeyer, 1996; Takahashi, 2011). Among such nutritional measures, some antibiotics such as monensin, lasalocid and salinomycin had also been tested for their effects in mitigating $\mathrm{CH}_{4}$ with successful applications (Van Nevel and Demeyer, 1996). However, the use of antibiotics as feed additives has received severe criticism due to their potential health risks for consumers. Antibiotics can be accumulated in animal products when being absorbed in digestive tract. They may also pass through the digestive tract (in excreta) and be released into the environment. Through any of these pathways, in turn, the use of antibiotics as feed additives may potentially be harmful to human through development of resistant pathogenic bacteria. A number of countries such as the EU countries have banned such use of antibiotics whilst some other countries are considering banning them (Makkar et al., 2007). Therefore, exploration for natural and safe feed additives that mitigate $\mathrm{CH}_{4}$ emissions while increase productivity of animals simultaneously or at least without hampering the respective productivity is urgently required.

Plant secondary compounds such as polyphenols, essential oils and saponins, which are typically high in tropical plants (Kamra et al., 2006; Jayanegara et al., 2011), have been considered as promising natural substances for mitigating $\mathrm{CH}_{4}$ emissions from ruminants. With regard to saponins, some main saponin-rich sources that have been repeatedly tested in relation to $\mathrm{CH}_{4}$ emissions were quillaja, yucca and tea. Indeed, different saponin-rich sources determined the effectiveness of such compounds in mitigating $\mathrm{CH}_{4}$ (Pen et al., 2006) although it still has to be proven across different studies. Apart from sourcedependent, levels of saponin additions apparently influenced the response as well. Graded addition levels of saponin-rich sources produced contrasting results, i.e. either decreased $\mathrm{CH}_{4}$ (e.g. Holtshausen et al., 2009) or limited significant effect (e.g. Staerfl et al., 2010). Therefore, in order to mediate such disagreement, the aim of the present study was to assess ruminal $\mathrm{CH}_{4}$ emissions through a metaanalytical approach of integrating related studies from published papers which described various levels of different saponin-rich sources being added to ruminant feed.

\section{MATERIALS AND METHODS}

\section{Database development}

A database was constructed from published literature reporting addition of saponin-rich sources at various levels and ruminal $\mathrm{CH}_{4}$ emissions in vitro. Accordingly, levels of saponin-rich source additions as well as different saponin sources were specified in the database. Scopus, ISI Web of Knowledge, EBSCO and Google Scholar were used as the searching tools to collect various related articles with the keywords "saponin" and " $\mathrm{CH}_{4}$ ". Apart from $\mathrm{CH}_{4}$, other related rumen fermentation parameters were also included in the database, i.e. organic matter digestibility (OMD), gas production, $\mathrm{pH}$, ammonia concentration, short-chain fatty acid (SCFA) profiles and protozoal count. Microbial population structure, including the methanogen population, was not pooled in the database due to limited studies reported the respective parameter.

Criteria for articles to be included in the database were: i) articles were published in English, ii) treatments included addition of saponin-rich sources to certain basal feeds, iii) saponin-rich sources were added independently from other interfering treatments, iv) $\mathrm{CH}_{4}$ emissions were directly measured, not obtained by any estimation procedures, and v) experiments were conducted based on in vitro rumen fermentation systems. The number of in vivo studies related to saponins and $\mathrm{CH}_{4}$ emissions using various ruminant species were few to date and therefore insufficient to be included in the current meta-analysis. Initially, by using the above-mentioned keywords, a total of 86 articles were found. After abstract evaluations, there were 45 potential articles to be included in the database. Full texts of these articles were then evaluated, and as a result, a total of 23 studies from 18 articles met the respective criteria (Table 1). When an article reported more than one experiment or study, each respective study was encoded separately.

As indicated in Table 1, the in vitro experiments had been conducted using Hohenheim gas test, Reading pressure technique, glass bottle incubation, rumen simulation technique, Tilley and Terry method, and in vitro continuous incubation system with various basal feeds each, with or without addition of concentrate. Levels of saponinrich sources added were expressed as $\mathrm{mg} / \mathrm{g}$ incubated substrate; when a study reported other units (e.g., $\mathrm{mg} / \mathrm{mL}$ incubation medium); a calculation was made based on available information within the respective study. Saponinrich sources included in the database were quillaja, gypsophilla, tribulus, tea and yucca plants, and the addition levels ranged from 0 (control) to $561.1 \mathrm{mg} / \mathrm{g}$ dry matter (DM). Presentation of meta-analysis results based on saponin contents rather than saponin-rich sources was not possible since a number of studies did not report their saponin contents. Sampling of gas for $\mathrm{CH}_{4}$ measurement was mainly performed at $24 \mathrm{~h}$ after incubation, and $\mathrm{CH}_{4}$ was measured by either infrared $\mathrm{CH}_{4}$ analyzer or gas chromatograph devices.

Prior to tabulation in the database, all data were transformed into similar units of measurements to allow direct analysis within a certain parameter. Some data were 
Table 1. Studies included in the meta-analysis of saponin-rich source addition on $\mathrm{CH}_{4}$ emission and rumen fermentation parameters in vitro

\begin{tabular}{|c|c|c|c|c|c|c|c|}
\hline $\begin{array}{l}\text { Study } \\
\text { no. }\end{array}$ & Reference & $\begin{array}{l}\text { In vitro } \\
\text { method }\end{array}$ & Basal feed & Saponin source & $\begin{array}{c}\text { Addition level } \\
(\mathrm{mg} / \mathrm{g} \\
\text { substrate })\end{array}$ & $\begin{array}{c}\text { Gas } \\
\text { sampling } \\
\text { (h) }\end{array}$ & $\begin{array}{c}\mathrm{CH}_{4} \\
\text { measurement }\end{array}$ \\
\hline 1 & $\begin{array}{l}\text { Castro-Montoya et al. } \\
\text { (2011) }\end{array}$ & HGT & $\begin{array}{l}\text { Hay-concentrate mixture } \\
(70: 30 \mathrm{w} / \mathrm{w})\end{array}$ & $\begin{array}{c}\text { Quillaja } \\
\text { (Quillaja saponaria), } \\
\text { Gypsophilla paniculata }\end{array}$ & $0-98.7$ & 24 & IR \\
\hline 2 & Feng et al. (2012) & HGT & $\begin{array}{l}\text { Chinese wildrye and corn grain } \\
(50: 50 \mathrm{w} / \mathrm{w})\end{array}$ & Tribulus terrestris & $0-135.0$ & 24 & GC \\
\hline 3 & Guo et al. (2008) & RPT & $\begin{array}{l}\text { Grass meal and corn meal } \\
(50: 50 \mathrm{w} / \mathrm{w})\end{array}$ & $\begin{array}{c}\text { Tea } \\
\text { (Camellia sineis) }\end{array}$ & 0 and 53.3 & 24 & GC \\
\hline 4 & Holtshausen et al. (2009) & GBI & Barley silage-based TMR & $\begin{array}{c}\text { Yucca } \\
\text { (Yucca schidigera), } \\
\text { Quillaja }\end{array}$ & $0-45.0$ & 24 & GC \\
\hline 5 & Hu et al. (2005a) & HGT & $\begin{array}{l}\text { Grass meal and corn meal } \\
(50: 50 \mathrm{w} / \mathrm{w})\end{array}$ & Tea & $0-40.0$ & 24 & GC \\
\hline 6 & Hu et al. (2005b) & RPT & $\begin{array}{l}\text { Grass meal and corn meal } \\
(50: 50 \mathrm{w} / \mathrm{w})\end{array}$ & Tea & $0-53.3$ & 24 & GC \\
\hline 7 & Hu et al. (2006) & RPT & $\begin{array}{l}\text { Grass meal and corn meal } \\
(50: 50 \mathrm{w} / \mathrm{w})\end{array}$ & Tea & $0-106.7$ & 24 & GC \\
\hline 8 & Khiaosa-ard et al. (2009) & Rusitec & Grass-clover hay & Yucca & 0 and 37.5 & 24 & GC \\
\hline 9 & Lila et al. (2003) & GBI & Soluble potato starch & Yucca & $0-480.0$ & 24 & GC \\
\hline 10 & Lila et al. (2003) & GBI & Cornstarch & Yucca & $0-480.0$ & 24 & GC \\
\hline 11 & Lila et al. (2003) & GBI & $\begin{array}{l}\text { Sudangrass-concentrate mixture } \\
(60: 40 \mathrm{w} / \mathrm{w})\end{array}$ & Yucca & $0-480.0$ & 24 & GC \\
\hline 12 & Malik and Singhal (2008) & TTM & $\begin{array}{l}\text { Wheat straw-concentrate mixture } \\
(60: 40 \mathrm{w} / \mathrm{w})\end{array}$ & Unspecified & $0-40.0$ & $8-96$ & GC \\
\hline 13 & Narvaez et al. (2013) & GBI & Barley silage-barley grain TMR & Yucca & 0 and 52.0 & 48 & GC \\
\hline 14 & Patra and Yu (2013) & GBI & $\begin{array}{l}\text { Alfalfa hay and concentrate } \\
(50: 50 \mathrm{w} / \mathrm{w})\end{array}$ & Quillaja & $0-120.0$ & 24 & $\mathrm{GC}$ \\
\hline 15 & Pen et al. (2006) & ICIS & $\begin{array}{l}\text { Oat hay and concentrate } \\
(50: 50 \mathrm{w} / \mathrm{w})\end{array}$ & Yucca & $0-561.1$ & 24 & IR \\
\hline 16 & Pen et al. (2006) & ICIS & $\begin{array}{l}\text { Oat hay and concentrate } \\
(50: 50 \mathrm{w} / \mathrm{w})\end{array}$ & Quillaja & $0-553.0$ & 24 & IR \\
\hline 17 & Pen et al. (2008) & ICIS & $\begin{array}{l}\text { Oat hay and concentrate } \\
(50: 50 \mathrm{w} / \mathrm{w})\end{array}$ & Quillaja & $0-368.6$ & 24 & IR \\
\hline 18 & Sliwinski et al. (2002) & Rusitec & $\begin{array}{l}\text { Grass silage, barley grain } \\
\text { and grass hay }\end{array}$ & Yucca & $0-8.0$ & 24 & GC \\
\hline 19 & Staerfl et al. (2010) & HGT & $\begin{array}{l}\text { Maize silage, soybean meal } \\
\text { and wheat }\end{array}$ & Yucca & $0-2.5$ & 48 & GC \\
\hline 20 & Wang et al. (1998) & Rusitec & $\begin{array}{l}\text { Alfalfa hay and barley-based } \\
\text { concentrate }(50: 50 \mathrm{v} / \mathrm{v})\end{array}$ & Yucca & 0 and 40.8 & 24 & GC \\
\hline 21 & Xu et al. (2010) & RPT & Switch grass & Yucca & 0 and 0.1 & 24 & GC \\
\hline 22 & Xu et al. (2010) & RPT & $\begin{array}{l}\text { Switch grass and concentrate } \\
(50: 50 \mathrm{w} / \mathrm{w})\end{array}$ & Yucca & 0 and 0.1 & 24 & GC \\
\hline 23 & Xu et al. (2010) & RPT & $\begin{array}{l}\text { Switch grass and concentrate } \\
(10: 90 \mathrm{w} / \mathrm{w})\end{array}$ & Yucca & 0 and 0.1 & 24 & GC \\
\hline
\end{tabular}

GBI, glass bottle incubation; GC, gas chromatograph; HGT, hohenheim gas test; ICIS, in vitro continuous incubation system; IR, infrared; RPT, reading pressure technique; Rusitec, rumen simulation technique; TMR, total mixed ration; TTM, Tilley and Terry method.

not complete or not reported uniformly. In such case, data were calculated from the available data if possible. Protozoal counts were normalized by applying logarithmic transformation.

\section{Statistical analysis}

The data obtained were subjected to a statistical metaanalysis based on mixed model methodology (St-Pierre, 2001; Sauvant et al., 2008). Accordingly, different studies were treated as random effects whereas levels of saponin- rich source additions or different saponin sources were considered as fixed effects.

There were two statistical models applied in the current meta-analysis study, depended on whether the predictor variable was continuous or discrete. For the continuous predictor variable, i.e. levels of saponin-rich source additions, the following model was used:

$$
Y_{\mathrm{ij}}=B_{0}+B_{1} X_{i j}+B_{2} X_{i j}^{2}+s_{i}+b_{i} X_{i j}+e_{i j}
$$


where $Y_{\mathrm{ij}}=$ dependent variable, $B_{0}=$ overall intercept across all studies (fixed effect), $B_{1}=$ linear regression coefficient of $Y$ on $X$ (fixed effect), $B_{2}=$ quadratic regression coefficient of $Y$ on $X$ (fixed effect), $X_{i j}=$ value of the continuous predictor variable (saponin addition level), $s_{i}$ $=$ random effect of study $i, b_{i}=$ random effect of study $i$ on the regression coefficient of $Y$ on $X$ in study $i$, and $e_{i j}=$ the unexplained residual error. When the respective quadratic regression model was not significant at $\mathrm{p}<0.05$, a linear regression model was applied. For the discrete predictor variable, i.e. various saponin sources, the following model was used:

$$
Y_{i j}=\mu+s_{i}+\tau_{j}+s \tau_{i j}+e_{i j}
$$

where $Y_{\mathrm{ij}}=$ dependent variable, $\mu=$ overall mean, $s_{i}=$ random effect of the $i$ th study, $\tau_{j}=$ fixed effect of the $j$ th level of factor $\tau, s \tau_{i j}=$ random interaction between the $i$ th study and the $j$ th level of factor $\tau$, and $e_{i j}=$ the unexplained residual error. When a variable showed significant difference at $p<0.05$ between various saponin sources, lsmeans statement was used to compare the difference between means.

Variable study and various saponin sources were stated in the class statement since they do not contain any quantitative information. Both models were used by weighting the observations with their incubation replicates as conducted by Jayanegara et al. (2012). During creation of graphical representation of results from multi-dimensional space of studies into two-dimensional space, the response variable (Y observation) was adjusted to take into account the random effect of study; this was done by adding the predicted $\mathrm{Y}$ values (the $\mathrm{Y}$ values on the regression line) with the residual (St-Pierre, 2001). Model statistics used were pvalue and root mean square error. Significance of an effect was stated when $\mathrm{p}$-value $<0.05$. Additionally, when the $\mathrm{p}$ value lay between 0.05 to 0.1 , an effect was stated as a tendency to be significant. All statistical analyses were performed with SAS Software version 9.1 (SAS Institute Inc., 2008).

\section{RESULTS}

Increasing the level of a saponin-rich source decreased $\mathrm{CH}_{4}$ emission per unit of substrate incubated with a curvilinear pattern ( $<<0.05$; Figure 1a). Saponin-rich source had little effectiveness in decreasing the respective $\mathrm{CH}_{4}$ parameter when added at approximately above $500 \mathrm{mg} / \mathrm{g}$ DM. When $\mathrm{CH}_{4}$ was expressed as $\mathrm{ml}$ per $100 \mathrm{~mL}$ total gas produced, increasing levels of the saponin-rich source decreased $\mathrm{CH}_{4}$ linearly $(\mathrm{p}<0.001$; Figure $1 \mathrm{~b})$. Total gas production decreased (curvilinear; $\mathrm{p}<0.05$ ) with an increasing level of saponin-rich source, and tended to

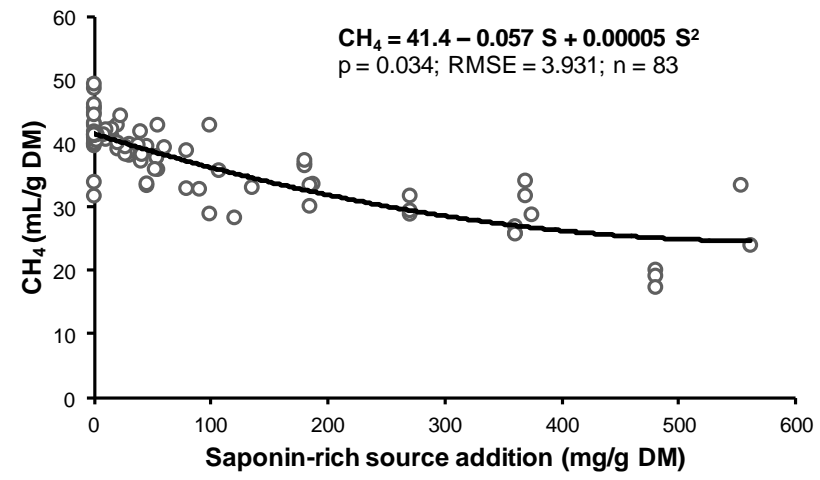

(a)

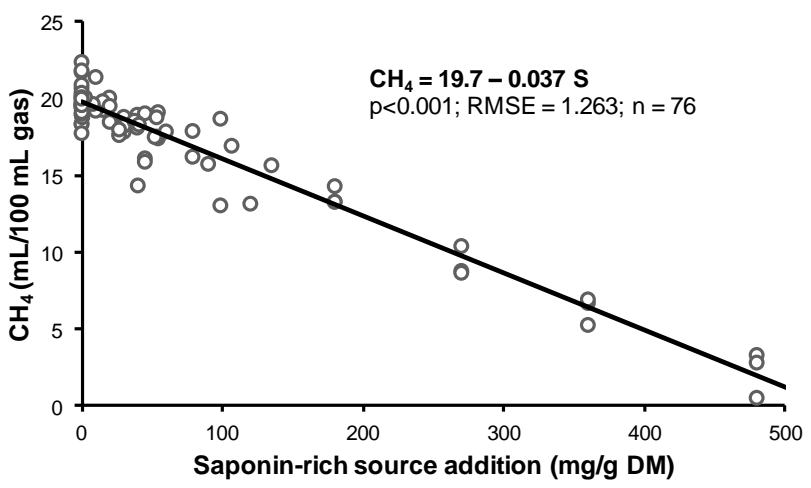

(b)

Figure 1. Relationship between saponin-rich source addition level and ruminal $\mathrm{CH}_{4}$ emission in vitro when presented as $\mathrm{ml} \mathrm{CH}_{4} / \mathrm{g}$ dry matter incubated (a) or as $\mathrm{ml} \mathrm{CH}_{4} / 100 \mathrm{ml}$ total gas production (b).

reduce OMD ( $\mathrm{p}<0.1)$ (Table 2). Rumen $\mathrm{NH}_{3}$ concentration also tended to decrease at higher levels of saponin $(\mathrm{p}<0.1)$. With regard to total SCFA production, the respective parameter increased linearly $(\mathrm{p}<0.001)$ with increasing levels of saponin-rich source. There was decrease in acetate proportion (linear pattern; $\mathrm{p}<0.05$ ) and an increase in propionate proportion (linear pattern; $\mathrm{p}<0.001$ ) from the total SCFA production with increasing levels of the saponins. Log protozoal count decreased significantly $(p<0.05)$ at higher saponin levels.

Comparing between different saponin-rich sources, all saponin sources appeared to produce less $\mathrm{CH}_{4}$ than the control. However, when $\mathrm{CH}_{4}$ was expressed as $\mathrm{mL} \mathrm{CH}_{4}$ produced per unit of incubated substrate, only yucca saponins had significantly lower $\mathrm{CH}_{4}$ than control $(\mathrm{p}<0.05)$, while quillaja and tea saponins were not different (Figure 2a). But when $\mathrm{CH}_{4}$ was expressed as $\mathrm{ml} \mathrm{CH}_{4}$ produced per $100 \mathrm{~mL}$ total gas, all saponin sources, i.e. quillaja, tea and yucca saponins produced less $\mathrm{CH}_{4}$ than that of control $(p<0.05)$ (Figure 2b). Although apparently the order of effectiveness of saponin-rich sources in mitigating $\mathrm{CH}_{4}$ was yucca>tea>quillaja, statistically they did not differ each other. All saponin-rich source additions did not decrease total gas production, OMD and total SCFA concentration 
Table 2. Regression equations on the influence of saponin-rich source addition level ( $\mathrm{S}$, in $\mathrm{mg} / \mathrm{g} \mathrm{DM})$ on ruminal fermentation parameters based on in vitro experiments

\begin{tabular}{|c|c|c|c|c|c|c|c|c|}
\hline \multirow{2}{*}{$\begin{array}{l}\text { Response } \\
\text { parameter }\end{array}$} & \multirow{2}{*}{$\begin{array}{l}\text { Dependent } \\
\text { factor }\end{array}$} & \multirow{2}{*}{$\mathrm{n}$} & \multicolumn{4}{|c|}{ Parameter estimates } & \multicolumn{2}{|c|}{ Model statistics } \\
\hline & & & Intercept & SE intercept & Slope & SE slope & p-value & RMSE \\
\hline \multirow[t]{2}{*}{ Gas (mL/g) } & $S$ & 70 & 196 & 15.8 & -0.019 & 0.031 & 0.548 & \\
\hline & $S^{2}$ & & & & 0.00019 & 0.00007 & 0.007 & 7.43 \\
\hline OMD (mg/g) & $S$ & 16 & 626 & 578.4 & -0.34 & 0.182 & 0.095 & 20.62 \\
\hline $\mathrm{pH}$ & S & 68 & 6.62 & 0.157 & -0.0001 & 0.0001 & 0.639 & 0.13 \\
\hline $\mathrm{NH}_{3}(\mathrm{mmol} / \mathrm{L})$ & $\mathrm{S}$ & 63 & 11.1 & 2.10 & -0.006 & 0.0034 & 0.092 & 2.92 \\
\hline Total SCFA ( mmol/L) & $\mathrm{S}$ & 89 & 75.3 & 5.96 & 0.010 & 0.0030 & $<0.001$ & 2.74 \\
\hline $\mathrm{C}_{2}(\%$ total $)$ & $S$ & 87 & 63.5 & 1.60 & -0.012 & 0.0017 & $<0.001$ & 1.54 \\
\hline $\mathrm{C}_{3}(\%$ total $)$ & $S$ & 87 & 22.0 & 0.94 & 0.012 & 0.0021 & $<0.001$ & 1.90 \\
\hline $\mathrm{C}_{4}(\%$ total $)$ & $S$ & 85 & 11.1 & 0.64 & -0.0004 & 0.0011 & 0.740 & 0.97 \\
\hline $\mathrm{C}_{5}(\%$ total $)$ & S & 51 & 2.81 & 0.440 & -0.0002 & 0.0002 & 0.350 & 0.14 \\
\hline isoSCFA (\% total) & $S$ & 53 & 3.00 & 0.505 & -0.0001 & 0.0004 & 0.978 & 0.21 \\
\hline $\mathrm{C}_{2}: \mathrm{C}_{3}$ & $S$ & 87 & 3.08 & 0.191 & -0.0014 & 0.0003 & $<0.001$ & 0.27 \\
\hline Log protozoa $\left(10^{4} / \mathrm{mL}\right)$ & S & 56 & 4.73 & 0.207 & -0.0006 & 0.0003 & 0.047 & 0.23 \\
\hline
\end{tabular}

DM, dry matter; $n$, number of observation; SE, standard error; RMSE, root mean square error; OMD, organic matter digestibility; SCFA, short chain fatty acid; $\mathrm{C}_{2}$, acetate; $\mathrm{C}_{3}$, propionate; $\mathrm{C}_{4}$, butyrate; $\mathrm{C}_{5}$, valerate.

compared to control (Table 3). Rumen $\mathrm{NH}_{3}$ on the addition of yucca saponins was lower than that of control $(\mathrm{p}<0.05)$, while the others were not. Acetate to propionate ratio was lower $(\mathrm{p}<0.05)$ than that of control when rations were added by all saponin-rich sources. All saponin-rich source

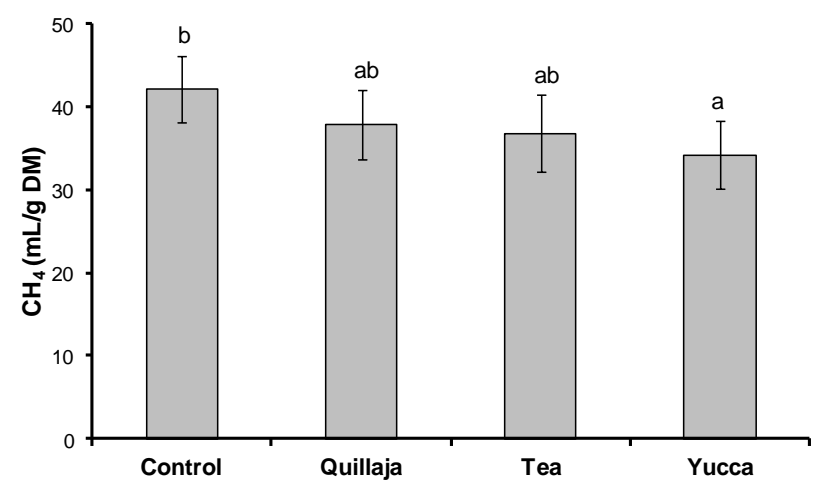

(a)

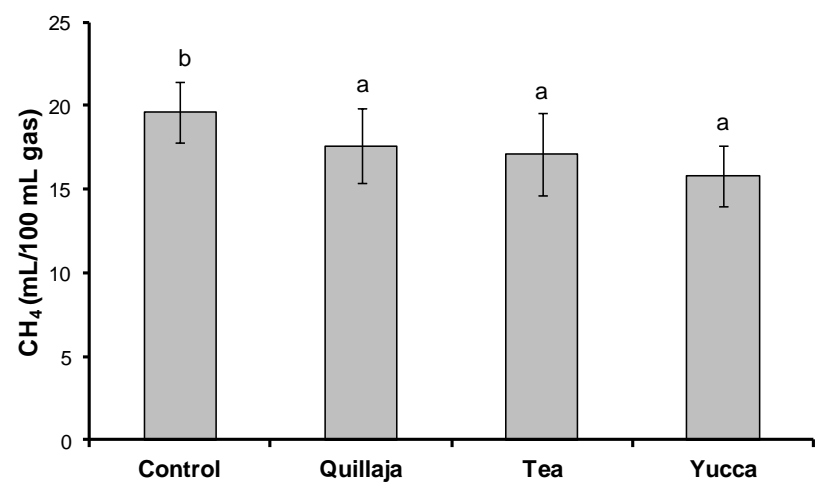

(b)

Figure 2. Effect of various saponin-rich sources on ruminal $\mathrm{CH}_{4}$

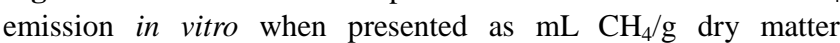
incubated (a) or as $\mathrm{ml} \mathrm{CH}_{4} / 100 \mathrm{~mL}$ total gas production (b). additions decreased log protozoal counts significantly $(\mathrm{p}<0.05)$.

\section{DISCUSSION}

\section{Influence of addition levels of saponin-rich sources}

Despite the large structural diversity of saponins among various plant sources (Francis et al., 2002; Wina et al., 2005), it appears that there is a genuine effect of increasing levels of saponin-rich source addition in mitigating ruminal $\mathrm{CH}_{4}$ emissions in vitro. Accordingly, $\mathrm{CH}_{4}$ emission (in $\mathrm{mL} / \mathrm{g} \mathrm{DM}$ ) decreased by following a curvilinear pattern; at addition level above $500 \mathrm{mg} / \mathrm{g}$ DM, saponin-rich source becomes ineffective in further decreasing $\mathrm{CH}_{4}$. However, when the unit of $\mathrm{CH}_{4}$ emission was expressed as $\mathrm{mL} / 100$ $\mathrm{mL}$ gas production, the relationship between saponin-rich source addition and $\mathrm{CH}_{4}$ followed a linear pattern with a negative slope between both variables. A possible explanation is that there was no data on the latter unit at saponin-rich source addition above $500 \mathrm{mg} / \mathrm{g} \mathrm{DM}$. If $\mathrm{CH}_{4}$ data at saponin-rich source addition above $500 \mathrm{mg} / \mathrm{g} \mathrm{DM}$ are removed from Figure 1a (Pen et al., 2006), apparently the relationship between the respective variables would become linear as in Figure 1b.

Part of the explanation that saponins decrease $\mathrm{CH}_{4}$ emissions is due to a lower relative abundance of the methanogen population in the presence of the respective substances in the rumen (Goel et al., 2008; Narvaez et al., 2013). Apart from a decrease in methanogen population, saponins may also hamper the activity of methanogen per unit of methanogen cells (Hess et al., 2003; Guo et al., 2008), although such depression of methanogen activity may not always be accompanied to a lower $\mathrm{CH}_{4}$ emission 
Table 3. Influence of various saponin-rich sources on ruminal fermentation parameters based on in vitro experiments

\begin{tabular}{lcccccc}
\hline Response parameter & $\mathrm{n}$ & Control & Quillaja saponin & Tea saponin & Yucca saponin & p-value \\
\hline Gas $(\mathrm{mL} / \mathrm{g})$ & 55 & 199 & 199 & 193 & 204 & 0.320 \\
$\mathrm{OMD}(\mathrm{mg} / \mathrm{g})$ & 16 & 620 & $\mathrm{Na}$ & 596 & 636 & 0.119 \\
$\mathrm{pH}$ & 63 & $6.64^{\mathrm{b}}$ & $6.71^{\mathrm{b}}$ & $6.58^{\mathrm{ab}}$ & $6.55^{\mathrm{a}}$ & 0.029 \\
$\mathrm{NH}_{3}(\mathrm{mmol} / \mathrm{L})$ & 58 & $12.77^{\mathrm{b}}$ & $11.62^{\mathrm{ab}}$ & $10.80^{\mathrm{ab}}$ & $8.94^{\mathrm{a}}$ & 0.002 \\
Total SCFA $(\mathrm{mmol} / \mathrm{L})$ & 74 & 74.7 & 78.2 & 75.6 & 75.6 & 0.090 \\
$\mathrm{C}_{2}(\%$ total $)$ & 72 & $63.0^{\mathrm{b}}$ & $61.4^{\mathrm{ab}}$ & $61.9^{\mathrm{ab}}$ & $60.5^{\mathrm{a}}$ & 0.001 \\
$\mathrm{C}_{3}(\%$ total $)$ & 72 & $21.9^{\mathrm{a}}$ & $23.7^{\mathrm{b}}$ & $23.7^{\mathrm{b}}$ & $24.4^{\mathrm{b}}$ & $<0.001$ \\
$\mathrm{C}_{4}(\%$ total $)$ & 70 & 11.3 & 11.0 & 10.7 & 11.3 & 0.618 \\
$\mathrm{C}_{5}(\%$ total $)$ & 45 & 2.78 & 2.84 & na & 2.79 & 0.735 \\
$i$ isoSCFA $(\%$ total $)$ & 47 & 3.02 & 2.99 & na & 2.99 & 0.906 \\
$\mathrm{C}_{2}: \mathrm{C}_{3}$ & 72 & $3.11^{\mathrm{b}}$ & $2.84^{\mathrm{a}}$ & $2.73^{\mathrm{a}}$ & $2.77^{\mathrm{a}}$ & $<0.001$ \\
Log protozoa $\left(10^{4} / \mathrm{mL}\right)$ & 45 & $4.81^{\mathrm{b}}$ & $4.57^{\mathrm{a}}$ & $4.65^{\mathrm{a}}$ & $4.65^{\mathrm{a}}$ & 0.006 \\
\hline
\end{tabular}

$\mathrm{n}$, number of observation; OMD, organic matter digestibility; na, data not available; SCFA, short chain fatty acid; $\mathrm{C}_{2}$, acetate; $\mathrm{C}_{3}$, propionate; $\mathrm{C}_{4}$, butyrate; $\mathrm{C}_{5}$, valerate.

Different superscripts within the same row are significantly different at $\mathrm{p}<0.05$.

(Goel et al., 2008). Unfortunately, these variables (i.e. methanogen population and methanogen activity) could not be integrated into the present meta-analysis study since there was insufficient data that was statistically justified from the published literature. Accordingly, protozoa provide hydrogen as a substrate for methanogenesis conducted by the methanogens (Morgavi et al., 2010). Therefore, a reduction in protozoa population (defaunation) may lead to a decrease in methanogen population and, subsequently, $\mathrm{CH}_{4}$ emission as well. Inhibition of cellulolytic bacteria and anaerobic fungi that degrade fibrous materials by the presence of saponins (Wina et al., 2005; Guo et al., 2008) leads to further decrease of hydrogen supply which in turn it contributes to lower $\mathrm{CH}_{4}$ emission.

With regard to SCFA production, the increase of total SCFA at higher levels of saponins is probably due to partial saponin degradation by rumen microbes (Wina et al., 2005) and thereafter the sugar moiety is utilized and fermented to produce SCFA. Concerning SCFA proportion, it could be clearly seen that higher levels of saponins shift the SCFA towards less acetate and more propionate and, as a consequence of that, lower acetate to propionate ratio. Such shifting plays a role as well in lowering $\mathrm{CH}_{4}$ emission since formation of acetate from sugar fermentation stoichiometrically produces hydrogen and, conversely, formation of propionate from sugar requires hydrogen, a central precursor for methanogenesis (Moss et al., 2000). The mechanism in which the shifting occurs is considered to be connected to the anti-protozoal effect of saponins (Wallace et al., 1994,2002). When the protozoa population is reduced in the presence of saponin-rich sources, acetate is concomitantly reduced since it is a product of protozoa metabolism from the fermentation of sugar. Further, methanogens associated with protozoa are decreased, and hence the electron transfer reaction has to search for an alternative pathway in which propionate (an alternative hydrogen sink) formation is stimulated (McAllister and Newbold, 2008). Additionally, some cellulolytic bacteria species such as Ruminococcus albus and Ruminococcus flavefaciens and some rumen fungi species such as Neocallimastix frontalis and Piromyces rhizinflata are inhibited by saponins (Patra and Saxena, 2009). Since fiberdegrading microorganisms are related to higher acetate production, inhibition of the cellulolytic bacteria and the anaerobic fungi species leads to a lower acetate to propionate ratio.

The decreased tendency to lower rumen $\mathrm{NH}_{3}$ concentration by higher levels of saponins apparently is related to predation intensity of protozoa to rumen bacteria. It has been widely known that protozoa ingest bacteria (Gutierrez and Davis, 1959), and such ingestion is accompanied by degradation of microbial protein into ammonia (Kurihara et al., 1968). When protozoa are partially inhibited by saponin-rich sources, predation intensity is reduced, and as consequence of that, rumen $\mathrm{NH}_{3}$ concentration is also decreased. Another explanation regarding such lower $\mathrm{NH}_{3}$ concentration in the presence of saponins is the interaction between $\mathrm{NH}_{3}$ and sugar moiety (glycon) of the substances and makes $\mathrm{NH}_{3}$ less available (Wallace et al., 1994). Saponins may also inhibit the growth and activity of rumen microbial species that contribute to protein degradation (e.g., Streptococcus bovis, Butyrivibrio fibrisolvens, and Prevotella bryantii) and, hence, lowering the extent of proteolysis and deamination (Wallace et al., 1994; Wang et al., 2000). Furthermore, ammonia concentrations in the rumen were much lower in ciliate-free animals in comparison to normal animals. Part of the explanation could be attributed to higher microbial synthesis on one hand and less bacterial recycling and bacteria proteolysis on the other hand when protozoa are 
missing (Firkins et al., 1998; Koenig et al., 2000; Eugene et al., 2004).

Based on the slopes and P-values of total gas production and OMD, it appears that higher levels of saponin-rich sources cause relatively minor effects on the respective parameters. In this case, saponin-rich sources possess a comparative advantage over tannin-rich sources in mitigating $\mathrm{CH}_{4}$ emission from ruminants. Accordingly, although higher levels of tannins mitigate $\mathrm{CH}_{4}$ emissions, marked reductions in total gas production and OMD were observed (Jayanegara et al., 2012), while this is apparently not the case for saponin-rich sources. This is supported by the total SCFA production parameter; there is no decrease of total SCFA by increasing levels of a saponin-rich source, instead, total SCFA increases.

In vivo feeding trials with inclusion of saponin-rich sources in diets of ruminants have been reported by some authors. For instance, Holtshausen et al. (2009) conducted a trial on early lactating dairy cows by adding either Yucca schidigera or Quillaja saponaria powder at a level of 10 $\mathrm{g} / \mathrm{kg}$ DM into a total mixed ration. The results showed that feeding saponin did not affect $\mathrm{CH}_{4}$ emission (measured either by using an environmental chamber or the $\mathrm{SF}_{6}$ method), rumen fermentation, nutrient digestibility (DM, crude protein, neutral detergent fiber, acid detergent fiber and gross energy) or milk production. In agreement with that, some authors have also reported an insignificant effect of a saponin-rich source addition on in vivo $\mathrm{CH}_{4}$ emissions of ruminants (Pen et al., 2007; Li and Powers, 2012). On the contrary, addition of $3 \mathrm{~g} / \mathrm{d}$ tea saponins in diets of growing lambs significantly decreased $\mathrm{CH}_{4}$ emissions from 26.2 to $19.0 \mathrm{~L} / \mathrm{kg}$ DMI as well as rumen protozoa populations compared with that of control diet. Further, tea saponin addition increased total SCFA production (without any change in the individual SCFA molar proportion) and microbial protein supply, although the addition did not alter daily gain of the lambs as compared to the control diet (Mao et al., 2010). There were also some other studies that observed a $\mathrm{CH}_{4}$ decrease in vivo on addition of saponin-rich sources into basal diets, i.e. Santoso et al. (2004), Wang et al. (2009), and Zhou et al. (2011). Thus, like in the in vitro studies, the effects of saponins on in vivo $\mathrm{CH}_{4}$ emissions from ruminants have produced contrasting results.

\section{Influence of various saponin-rich sources}

Saponins are a class of plant secondary compounds that possess a great complexity in their structures as well as their biological activities. Basically, chemical structure of saponins consists of a sugar moiety (glucose, galactose, glucoronic acid, xylose, rhamnose, or methylpentose) that glycosidically linked to a hydrophobic aglycone or sapogenin (Francis et al., 2002). Accordingly, saponins could be broadly classified based on their sapogenin structure, i.e. either triterpenoid saponins or steroid saponins (Wina et al., 2005) although other classifications exist (Vincken et al., 2007). Main saponins present in quillaja and tea are triterpenoid saponins (Guo et al., 1998; Zhao et al., 2011) while steroid saponins are predominant in yucca (Oleszek et al., 2001).

Addition of quillaja, tea or yucca decreased ruminal $\mathrm{CH}_{4}$ emission (in $\mathrm{mL} / \mathrm{g} \mathrm{DM}$ ) by $7.9 \%, 13.0 \%$, or $22.3 \%$ as compared to control, respectively. When the $\mathrm{CH}_{4}$ unit is presented as $\mathrm{mL} / 100 \mathrm{~mL}$ total gas, addition of quillaja, tea or yucca decreased the emission by $9.5 \%, 13.2 \%$, or $23.3 \%$ than that of control, respectively. The respective figures may suggest that steroid saponins are presumably more effective in mitigating ruminal $\mathrm{CH}_{4}$ emissions compared to those of triterpenoid saponins. Perhaps such effects are related to anti-protozoal properties of saponins; saponins cause a change in cell membrane permeability by forming complexes with cholesterol in protozoal cell membranes and provoke cell lysis (Pen et al., 2008). Hypothetically, hydrophobic interaction between steroid saponins with such membrane cholesterol seems to be more effective in causing protozoa cell lysis than that of triterpenoid saponins. However, the hypothesis could not be directly proven from this study since no significant differences occurred on log protozoa population between the three saponin-rich sources. Further study is therefore required in order to elucidate exact mechanisms on how various sapogenin structures influence protozoa cell structure, activity and metabolism.

Apart from the diversity in the aglycone structures between quillaja, tea and yucca saponins, the difference in sugar moiety among such sources may also explain their distinct activities (Wina et al., 2006). Accordingly, biological activity of saponins depends on the nature, number and sequence of the sugars in the structures (Chwalek et al., 2006). Monodesmosidic saponins (saponin with a single sugar chain), for instance, are generally more active than bidesmosidic saponins (saponin with two sugar chains) (Voutquenne et al., 2002). Further, substitution of a monosaccharide with another monosaccharide within the sugar chain may change biological activity of saponins (Chwalek et al., 2006). It is however quite difficult to fully understand the structure-activity relationships of saponins due to the large structural diversity of the substances (both the sapogenin and the sugar moiety) even within a single plant species (Guo et al., 1998; Oleszek et al., 2001; Zhao et al., 2011). It has to be noted as well that what is compared in the present meta-analysis study is various saponin-rich sources or saponin-containing plants, not the purified form of saponins. This means that other confounding components, either nutritional or non-nutritional compounds, are present and cannot be neglected regarding their roles in rumen fermentation including methanogenesis. 


\section{CONCLUSION}

The present meta-analysis study shows that, based on various experiments, increasing levels of a saponin-rich source lead to a decrease of ruminal $\mathrm{CH}_{4}$ emissions in vitro. Interestingly, higher levels of the saponins do not negatively influence digestibility and total SCFA production. The $\mathrm{CH}_{4}$ decrease with increasing levels of saponins is apparently due to a lower acetate to propionate ratio and a lower protozoal counts. Various saponin-rich source additions reveal different responses in ruminal $\mathrm{CH}_{4}$ emissions. Previous studies arrived in contrasting results of saponin effects on $\mathrm{CH}_{4}$ emissions can therefore be explained through the present study, at least partially, i.e. $\mathrm{CH}_{4}$ mitigating properties of saponins in the rumen are leveland source-dependent.

\section{REFERENCES}

Castro-Montoya, J. M., H. P. S. Makkar, and K. Becker. 2011. Chemical composition of rumen microbial fraction and fermentation parameters as affected by tannins and saponins using an in vitro rumen fermentation system. Can. J. Anim. Sci. 91:433-448.

Chwalek, M., N. Lalun, H. Bobichon, K. Ple, and L. VoutquenneNazabadioko. 2006. Structure-activity relationships of some hederagenin diglycosides: Haemolysis, cytotoxicity and apoptosis induction. Biochim. Biophys. Acta 1760:1418-1427.

Cottle, D. J., J. V. Nolan, and S. G. Wiedemann. 2011. Ruminant enteric methane mitigation: a review. Anim. Prod. Sci. 51:491514.

Desnoyers, M., S. Giger-Reverdin, G. Bertin, C. Duvaux-Ponter, and D. Sauvant. 2009. Meta-analysis of the influence of Saccharomyces cerevisiae supplementation on ruminal parameters and milk production of ruminants. J. Dairy Sci. 92:1620-1632.

Eugene, M., H. Archimede, and D. Sauvant. 2004. Quantitative meta-analysis on the effects of defaunation of the rumen on growth, intake and digestion in ruminants. Livest. Prod. Sci. 85:81-97.

Feng, Z. H., Y. F. Cao, Y. X. Gao, Q. F. Li, and J. G. Li. 2012. Effect of gross saponin of Tribulus terrestris on ruminal fermentation and methane production in vitro. J. Anim. Vet. Adv. 11:2121-2125.

Finlay, B. J., G. Esteban, K. J. Clarke, A. G. Williams, T. M. Embley, and R. P. Hirt. 1994. Some rumen ciliates have endosymbiotic methanogens. FEMS Microbiol. Lett. 117:157161.

Firkins, J. L., M. S. Allen, B. S. Oldick, and N. R. St-Pierre. 1998. Modeling ruminal digestibility of carbohydrates and microbial protein flow to the duodenum. J. Dairy Sci. 81:3350-3369.

Francis, G., Z. Kerem, H. P. S. Makkar, and K. Becker. 2002. The biological action of saponins in animal systems: A review. Br. J. Nutr. 88:587-605.

Goel, G., H. P. S. Makkar, and K. Becker. 2008. Changes in microbial community structure, methanogenesis and rumen fermentation in response to saponin-rich fractions from different plant materials. J. Appl. Microbiol. 105:770-777.

Guo, S., L. Kenne, L. N. Lundgren, B. Ronnberg, and B. G. Sundquist. 1998. Triterpenoid saponins from Quillaja saponaria. Phytochemistry 48:175-180.

Guo, Y. Q., J. X. Liu, Y. Lu, W. Y. Zhu, S. E. Denman, and C. S. McSweeney. 2008. Effect of tea saponin on methanogenesis, microbial community structure and expression of $m c r A$ gene, in cultures of rumen micro-organisms. Lett. Appl. Microbiol. 47:421-426.

Gutierrez, J. and R. E. Davis. 1959. Bacterial ingestion by the rumen ciliates Entodinium and Diplodinium. J. Eukaryot. Microbiol. 6:222-226.

Hegarty, R. S. 1999. Reducing rumen methane emissions through elimination of rumen protozoa. Aust. J. Agric. Res. 50:13211328.

Hess, H. D., M. Kreuzer, T. E. Diaz, C. E. Lascano, J. E. Carulla, C. R. Soliva, and A. Machmueller. 2003. Saponin rich tropical fruits affect fermentation and methanogenesis in faunated and defaunated rumen fluid. Anim. Feed Sci. Technol. 109:79-94.

Holtshausen, L., A. V. Chaves, K. A. Beauchemin, S. M. McGinn, T. A. McAllister, N. E. Odongo, P. R. Cheeke, and C. Benchaar. 2009. Feeding saponin-containing Yucca schidigera and Quillaja saponaria to decrease enteric methane production in dairy cows. J. Dairy Sci. 92:2809-2821.

Hu, W. L., J. X. Liu, J. A. Ye, Y. M. Wu, and Y. Q. Guo. 2005a. Effect of tea saponin on rumen fermentation in vitro. Anim. Feed Sci. Technol. 120:333-339.

Hu, W. L., Y. M. Wu, J. X. Liu, Y. Q. Guo, and J. A. Ye. 2005b. Tea saponins affect in vitro fermentation and methanogenesis in faunated and defaunated rumen fluid. J. Zhejiang Univ. Sci. 6B:787-792.

Hu, W. L., J. X. Liu, Y. M. Wu, Y. Q. Guo, and J. A. Ye. 2006. Effects of tea saponins on in vitro ruminal fermentation and growth performance in growing Boer goat. Arch. Anim. Nutr. 60:89-97.

Jayanegara, A., M. Kreuzer, E. Wina, and F. Leiber. 2011. Significance of phenolic compounds in tropical forages for the ruminal bypass of polyunsaturated fatty acids and the appearance of biohydrogenation intermediates as examined in vitro. Anim. Prod. Sci. 51:1127-1136.

Jayanegara, A., F. Leiber, and M. Kreuzer. 2012. Meta-analysis of the relationship between dietary tanin level and methane formation in ruminants from in vivo and in vitro experiments. J. Anim. Physiol. Anim. Nutr. 96:365-375.

Kamra, D. N., N. Agarwal, and L. C. Chaudhary. 2006. Inhibition of ruminal methanogenesis by tropical plants containing secondary compounds. Int. Congr. Ser. 1293:156-163.

Khiaosa-ard, R., S. F. Bryner, M. R. L. Scheeder, H. R. Wettstein, F. Leiber, M. Kreuzer, and C. R. Soliva. 2009. Evidence for the inhibition of the terminal step of ruminal $\alpha$-linolenic acid biohydrogenation by condensed tannins. J. Dairy Sci. 92:177188

Koenig, K. M., C. J. Newbold, F. M. McIntosh, and L. M. Rode. 2000. Effects of protozoa on bacterial nitrogen recycling in the rumen. J. Anim. Sci. 78:2431-2445.

Kurihara, Y., J. M. Eadie, P. N. Hobson, and S. O. Mann. 1968. Relationship between bacteria and ciliate protozoa in the sheep rumen. J. Gen. Microbiol. 51:267-288.

Lassey, K. R. 2008. Livestock methane emission and its 
perspective in the global methane cycle. Aust. J. Exp. Agric. 48:114-118.

Li, W. and W. Powers. 2012. Effects of saponin extracts on air emissions from steers. J. Anim. Sci. 90:4001-4013.

Lila, Z. A., N. Mohammed, S. Kanda, T. Kamada, and H. Itabashi. 2003. Effect of sarsaponin on ruminal fermentation with particular reference to methane production in vitro. J. Dairy Sci. 86:3330-3336.

Makkar, H. P. S., G. Francis, and K. Becker. 2007. Bioactivity of phytochemicals in some lesser-known plants and their effects and potential applications in livestock and aquaculture production systems. Animal 1:1371-1391.

Malik, P. K. and K. K. Singhal. 2008. Influence of supplementation of wheat straw based total mixed ration with saponins on total gas and methane production in vitro. Indian $\mathrm{J}$. Anim. Sci. 78:987-990.

Mao, H. L., J. K. Wang, Y. Y. Zhou, and J. X. Liu. 2010. Effects of addition of tea saponins and soybean oil on methane production, fermentation and microbial population in the rumen of growing lambs. Livest. Sci. 129:56-62.

McAllister, T. A. and C. J. Newbold. 2008. Redirecting rumen fermentation to reduce methanogenesis. Aust. J. Exp. Agric. 48:7-13.

Monteny, G. J., A. Bannink, and D. Chadwick. 2006. Greenhouse gas abatement strategies for animal husbandry. Agric. Ecosyst. Environ. 112:163-170.

Morgavi, D. P., E. Forano, C. Martin, and C. J. Newbold. 2010. Microbial ecosystem and methanogenesis in ruminants. Animal 4:1024-1036.

Moss, A. R., J. P. Jouany, and J. Newbold. 2000. Methane production by ruminants: its contribution to global warming. Ann. Zootech. 49:231-253.

Narvaez, N., Y. Wang, and T. McAllister. 2013. Effects of extracts of Humulus lupulus (hops) and Yucca schidigera applied alone or in combination with monensin on rumen fermentation and microbial populations in vitro. J. Sci. Food Agric. 93:25172522.

Newbold, C. J., B. Lassalas, and J. P. Jouany. 1995. The importance of methanogens associated with ciliate protozoa in ruminal methane production in vitro. Lett. Appl. Microbiol. 21:230-234.

Oleszek, W., M. Sitek, A. Stochmal, S. Piacente, C. Pizza, and P. Cheeke. 2001. Steroidal saponins of Yucca schidigera Roezl. J. Agric. Food Chem. 49:4392-4396.

Patra, A. K. and J. Saxena. 2009. The effect and mode of action of saponins on the microbial populations and fermentation in the rumen and ruminant production. Nutr. Res. Rev. 22:204-219.

Patra, A. K. and Z. Yu. 2013. Effective reduction of enteric methane production by a combination of nitrate and saponin without adverse effect on feed degradability, fermentation, or bacterial and archaeal communities of the rumen. Bioresour. Technol. 148:352-360.

Pen, B., C. Sar, B. Mwenya, K. Kuwaki, R. Morikawa, and J. Takahashi. 2006. Effects of Yucca schidigera and Quillaja saponaria extracts on in vitro ruminal fermentation and methane emission. Anim. Feed Sci. Technol. 129:175-186.

Pen, B., K. Takaura, S. Yamaguchi, R. Asa, and J. Takahashi. 2007. Effects of Yucca schidigera and Quillaja saponaria with or without $\quad \begin{array}{lll}1-4 & \text { galacto-oligosaccharides on ruminal }\end{array}$ fermentation, methane production and nitrogen utilization in sheep. Anim. Feed Sci. Technol. 138:75-88.

Pen, B., C. Sar, B. Mwenya, and J. Takahashi. 2008. Effects of Quillaja saponaria extract alone or in combination with Yucca schidigera extract on ruminal fermentation and methanogenesis in vitro. Anim. Sci. J. 79:193-199.

Santoso, B., B. Mwenya, C. Sar, Y. Gamo, T. Kobayashi, R. Morikawa, K. Kimura, H. Mizukoshi, and J. Takahashi. 2004. Effects of supplementing galacto-oligosaccharides, Yucca schidigera or nisin on rumen methanogenesis, nitrogen and energy metabolism in sheep. Livest. Prod. Sci. 91:209-217.

SAS Institute Inc. 2008. SAS/STAT Software version 9.1. SAS Institute Inc., Cary, NC, USA.

Sauvant, D., P. Schmidely, J. J. Daudin, and N. R. St-Pierre. 2008. Meta-analyses of experimental data in animal nutrition. Animal 2:1203-1214.

Sliwinski, B. J., C. R. Soliva, A. Machmueller, and M. Kreuzer. 2002. Efficacy of plant extracts rich in secondary constituents to modify rumen fermentation. Anim. Feed Sci. Technol. 101:101-114.

Staerfl, S. M., M. Kreuzer, and C. R. Soliva. 2010. In vitro screening of unconventional feeds and various natural supplements for their ruminal methane mitigation potential when included in a maize-silage based diet. J. Anim. Feed Sci. 19:651-664.

St-Pierre, N. R. 2001. Integrating quantitative findings from multiple studies using mixed model methodology. J. Dairy Sci. 84:741-755.

Takahashi, J. 2011. Some prophylactic options to mitigate methane emission from animal agriculture in Japan. Asian Australas. J. Anim. Sci. 24:285-294.

Thorpe, A. 2009. Enteric fermentation and ruminant eructation: the role (and control?) of methane in the climate change debate. Clim. Change 93:407-431.

Van Nevel, C. J. and D. I. Demeyer. 1996. Control of rumen methanogenesis. Environ. Monit. Assess. 42:73-97.

Vincken, J. P., L. Heng, A. de Groot, and H. Gruppen. 2007. Saponins, classification and occurrence in the plant kingdom. Phytochemistry 68:275-297.

Voutquenne, L., C. Lavaud, G. Massiot, and Le Men-Olivier. 2002. Structure-activity relationships of haemolytic saponins. Pharm. Biol. 40:253-262.

Wallace, R. J., L. Arthaud, and C. J. Newbold. 1994. Influence of Yucca schidigera extract on ruminal ammonia concentrations and ruminal microorganisms. Appl. Environ. Microbiol. 60:1762-1767.

Wallace, R. J., N. R. McEwan, F. M. McIntosh, B. Teferedegne, and C. J. Newbold. 2002. Natural products as manipulators of rumen fermentation. Asian Australas. J. Anim. Sci. 15:14581468.

Wang, Y., T. A. McAllister, C. J. Newbold, L. M. Rode, P. R. Cheeke, and K. J. Cheng. 1998. Effects of Yucca schidigera extract on fermentation and degradation of steroidal saponins in the rumen simulation technique (RUSITEC). Anim. Feed Sci. Technol. 74:143-153.

Wang, Y., T. A. McAllister, L. J. Yanke, and P. R. Cheeke. 2000. Effect of steroidal saponin from Yucca schidigera extract on ruminal microbes. J. Appl. Microbiol. 88:887-896.

Wang, C. J., S. P. Wang, and H. Zhou. 2009. Influences of 
flavomycin, ropadiar, and saponin on nutrient digestibility, rumen fermentation, and methane emission from sheep. Anim. Feed Sci. Technol. 148:157-166.

Wina, E., S. Muetzel, and K. Becker. 2005. The impact of saponins or saponin-containing plant materials on ruminant production - A review. J. Agric. Food Chem. 53:8093-8105.

Wina, E., S. Muetzel, and K. Becker. 2006. Effects of daily and interval feeding of Sapindus rarak saponins on protozoa, rumen fermentation parameters and digestibility in sheep. Asian Australas. J. Anim. Sci. 19:1580-1587.
Xu, M., M. Rinker, K. R. McLeod, and D. L. Harmon. 2010. Yucca schidigera extract decreases in vitro methane production in a variety of forages and diets. Anim. Feed Sci. Technol. 159:18-26.

Zhao, P., D. F. Gao, M. Xu, Z. G. Shi, D. Wang, C. R. Yang, and Y. J. Zhang. 2011. Triterpenoid saponins from the genus camellia. Chem. Biodivers. 8:1931-1942.

Zhou, Y. Y., H. L. Mao, F. Jiang, J. K. Wang, J. X. Liu, and C. S. McSweeney. 2011. Inhibition of rumen methanogenesis by tea saponins with reference to fermentation pattern and microbial communities in Hu sheep. Anim. Feed Sci. Technol. 166167:93-100. 